\title{
ETHNIC-DEMOGRAPHIC CHANGES IN THE DATA OF THE STATISTICAL SOURCES OF THE CITY OF VILNIUS (1920-1939)
}

\author{
Vitalija Stravinskiené
}

\begin{abstract}
The article deals with the ethnic-demographic developments in the city of Vilnius in 1920-1939, the 'Polish' period, when Poles in 1920 occupied Vilnius by armed means and quickly incorporated it into Poland. Due to political, socio-economic and cultural factors (the ethnic policy undertaken by Poland, the importance of Vilnius as the political-economic, cultural-education centre, processes of intensive migration, etc), significant ethnic-demographic changes occurred in the city. It became an attractive object for the Polish population, the number of people of Polish nationality, mainly due to migration, increased steadily (from 70,000 in 1920, to about 130,000 in 1939). During the discussed period, Vilnius was a Polish-Jewish city, in which by 1939, Poles accounted for about 66 per cent, and Jews about 29 per cent of the city's population.
\end{abstract}

\section{Introduction}

The residents of the city of Vilnius at various times in history experienced radical changes. The city was repeatedly ravaged by war, famine and disease. Historical developments in the first half of the 20th century were no exception: the First World War was accompanied by the conflicting interests of the emerging modern states of Lithuania and Poland over the city. After a military takeover and the subsequent incorporation of the city into Poland, Polish government institutions acted to promote and monitor the processes of its demographic development in 1920-1939.

There has been little research into demographic issues in the city of Vilnius in the first half of the 20th century. Usually, investi gating the demographic changes in Vilnius in a broader historical sense or in the context of the second half of the 20th century, the situation 
in the first half of the 20th century was reviewed only briefly ${ }^{1}$. In other works written through the prism of ethnic-demographic processes in the Vilnius region, there was also an occasional mention of the demographic situation in Vilnius in our analysed period ${ }^{2}$. In the mentioned works, the effect of political processes on the region's demographic development is disclosed, and attention is drawn to the importance of migration, and the then government's efforts to regulate it. The American historian T. Weeks ${ }^{3}$, after reviewing the situation in Vilnius in the first quarter of the 20th century, noted that due to political changes in a short period of time, the Russian Вильна was transformed into the Polish Wilno. The government of Poland strengthened the Polish identity of the city.

Authors writing during the interwar years were also interested in the demographic situation in Vilnius and the ethnic structure of the population. The economist Albert Tarulis identified two phases in the demographic development of the city: their dividing line was 1932, when the until then rapidly growing population of the city stabilized until the start of the Second World $\mathrm{War}^{4}$. He mentions the weak economic situation in the city as the main reason for this situation.

${ }^{1}$ V. Stankūnienè, Demographic Development of Vilnius in Historical Context, Lietuvos demografiniai pokyčiai ir gyventoju politika, ed. V. Stankūnienè et al. (Vilnius, 1995), pp. 21-41; P. Gaučas, M. Karalienè, 'Dabartinès Vilniaus gyventojų nacionalinès sudèties kitimo tendencijos', Lietuvos TSR Aukštuju mokyklu mokslo darbai. Geografija, 17 (1981), pp. 124-145; A. Stanaitis, 'Tautiniai pokyčiai Vilniaus mieste XX a. II puseje', Geografija, 39 (2003), pp. 33-39.

2 P. Gaučas, Etnolingvistine Rytu Lietuvos gyventoju raida. XVII a. antroji pusé - 1939 (Vilnius, 2004); Z. Zinkevičius, Rytu Lietuva praeityje ir dabar (Vilnius, 1993), pp. 161-165. B. Makauskas, Vilnijos lietuviai 1920-1939 metais (Vilnius, 1991); A. Vidugiris, 'Etnolingvistinè Pietryčių Lietuvos padètis XX a. pirmojoje pusèje', Lietuvos Rytai, ed. K. Garšva, L. Grumadienè (Vilnius, 1993), p. 125; I. Petrauskienè, 'Lenkijos valdžios antilenkiška politika Vilnijoje 1935-1939 m.', Rytu Lietuva (Vilnius, 1992), pp. 72-98; A. Budreckis, 'Vilniaus krašto demografinès problemos', Rytu Lietuva (Chicago, 1980), pp. 299-338; J. Januszewska-Jurkiewicz, Stosunki narodowościowe na Wileńszczyźnie w latach 1920-1939 (Katowice, 2010); A. Srebrakowski, 'Zmiany składu narodowościowego w części Wileńszczyzny wcielonej do Litwy w okresie II wojny światowej’, Przemiany narodowościowe na Kresach wschodnich II Rzeczypospolitej 1931-1947, ed. S. Ciesielski (Toruń, 2004), pp. 324-350; P. Eberhardt, Przemiany narodowościowe na Litwie (Warsaw, 1997), pp. 114-127.

${ }^{3}$ T. Weeks, From 'Russian' to 'Polish': Vilna-Wilno 1900-1925, access through $<$ http://www.ucis.pitt.edu/nceeer/2004_819-06g_Weeks.pdf $>$.

${ }^{4}$ A. Tarulis, 'Vilnius ir Kaunas', Tautos ūkis, 1939, No. 51-52, p. 952. 
One may note that in 1920-1939, the views of Lithuanian and Polish writers on the ethnic structure of the city differed considerably. Based on various statistical data, they tried to show the Lithuanian or Polish identity of Vilnius. For example, Janusz Ostrowski, Alfons Krysiński and Stanisław Gorzuchowski, based on Polish statistics, stated that in the 1920s and 1930s the number of Lithuanians in Vilnius was minimal, and amounted 3,000 to $3,500^{5}$. Lithuanian authors disputed these claims. Jews and Lithuanians were identified as the dominant groups of inhabitants ${ }^{6}$. In general, one may emphasise that Lithuanian society in 1920-1939 paid great attention to the Vilnius issue. The assimilation policy of the Polish state with regard to the Lithuanians of Vilnius and the Vilnius region, and their efforts to retain their Lithuanian identity, were described in various publications and the press. The campaigns on the issue of Vilnius (for example, in 1923 the 600th anniversary of the founding of Vilnius, in 1925 the founding of the Union to Liberate Vilnius, on 9 October, the Vilnius Days of Mourning commemorations, in 1932 the issue of Vilnius passports started, etc) were reported ${ }^{7}$.

One may note that the data of Polish and Lithuanian authors, as well as that of the official Polish statistics on the number of Lithuanians in Vilnius, can be corrected. Archival sources would testify to this. The Curia of the Vilnius Archdiocese was not interested in increasing the number of Lithuanians in the city. So according to its data, in 1934 in Vilnius there were 5,000 Lithuanian Catholics, and 2,000 Belarusians, although according to the official statistics, the first figure was 1,579 , and the second $1,737^{8}$.

5 J. Ostrowski, 'Litwini na ziemi Wileńskiej', Wilno i Ziemia Wileńska, I (Vilnius, 1930), pp. 226-249; A. Krysiński, 'Ludność polska a mniejszości w Polsce w świetle spisów ludności 1921 i 1931', Sprawy Narodowościowe, 1933, No. 4-5, pp. 3-47; S. Gorzuchowski, 'Ludność litewska na kresach państwa polskiego', Sprawy Narodowościowe, 1929, No. 1, p. 3-23.

${ }^{6}$ Vilnius ir Vilniaus kraštas (Kaunas, 1932), pp. 120-121.

${ }^{7}$ See B. Šèmis [M. Biržiška], Vilniaus Golgota. Okupuotosios Lietuvos lietuviu darbo ir kančiu 1919-1928 metu dienoraštis iš laikraščiu surinktas (Kaunas, 1930); V. Steponaitis, Vilniaus lietuviu spauda 1919-1928 (Kaunas, 1931); Laisvoji Lietuva be Vilniaus (Kaunas, 1935); M. Urbšienè, Sąrašas aktualių knygu ir rašiniu apie Vilniu ir Vilniaus krašta (Kaunas, 1939); D. Mačiulis, Apie dvi propagandines kampanijas XX a. tarpukario Lietuvoje, access through $<$ http://archive.minfolit.lt/ $\operatorname{arch} / 20501 / 20825$.pdf. $>$ [address visited on 2012-07-15].

8 Vilnius Archdiocese statistical data for 1934, MAVB RS, f. 318-10271, fos. 1-2; Drugi powszechny spis ludności a dnia 9 XII 1931 r. Miasto Wilno (Warsaw, 1937), p. 11. 
Some researchers (Jerzy Tomaszewski, Janusz Żarnowski, Petras Kalnius, Petras Gaučas, Marijona Karalienè) have drawn attention to the problem of the statistical reliability of the sources, noting that the only census of the population in the period in question (in 1931), and especially its data on the ethnic composition of the population, was unobjective. ${ }^{9}$ One can agree with these authors. Archival materials have confirmed that there were attempts to adjust the figures. The official Polish statistics were then intended for the general public, they were used for purposes of political conjuncture. However, when there are no possibilities to verify them, it is essential to compare them with other unpublished or unofficial statistical sources. Information and data (different responses to letters, explanations, etc) designated for the internal use of institutions of Poland's government would seem more reliable.

The basis for this article is the material and published statistical compendiums stored in the archives and manuscript collections of Lithuania.

In the Lithuanian Central State Archives (LCSA) documents are stored reflecting the activities of the Vilnius city magistrate, the wojewoda of Vilnius, the Polish government delegate in Vilnius, the city commissioner and starosta of Vilnius. From these the documents of the Statistics Division of the Vilnius Magistrate stand out, on the basis of which the city's population dynamics during the period were determined, the mechanical gain in different periods was calculated, comparing it with published statistical material, the ratio of the mechanical to the natural increase was reviewed, and so on.

Documents of Poland's administrative government of the time help to determine factors on the city's demographic changes. They confirm that there was an attempt to control the city's ethnic demographic processes with the help of various ordinances, regulations and prohibitions.

Documents stored in the Manuscript Department of the Lithuanian Academy of Sciences' Wróblewski Library helped to evaluate the

9 J. Tomaszewski, Ojczyzna nie tylko Polaków. Mniejszości narodowe w Polsce w latach 1918-1939 (Warsaw, 1983), p. 37; J. Żarnowski, Spoleczeństwo Drugiej Rzeczypospolitej 1918-1939 (Warsaw, 1973), p. 372-373; P. Kalnius, 'Paslèptieji' etnodemografiniai pokyčiai Lietuvoje XIX a. antrojoje pusejje - XX a. pirmojoje pusèje, Lietuvos kataliku mokslo akademijos metraštis, 21 (2002), p. 485; Gaučas, Karalienè, 'Dabartinès Vilniaus gyventojų nacionalinès sudèties kitimo tendencijos', p. 130 . 
reliability of the Polish official statistics on the ethnic composition of the city's population (according to the 1931 census). The data shows that during the population census, there was an effort to reduce the number of non-Poles in the city. The data stored in the Manuscript Department collected by the Vilnius Archdiocese revised and supplemented the facts mentioned in other sources.

Based on historiographical and archival material, the article analyses changes in the ethnic-demographic situation of the city in 1920-1939, revealing the factors that determined its dynamics. It should be noted that the ethnic structure of the city was changed by political methods: the quantitatively dominant residents in Vilnius at the end of the 19th century the Jews, surrendered this place to the Poles at the beginning of the analysed period. The Polish government pursued the modernisation of the state, and this was especially relevant in the eastern borderlands of the country (these territories were little urbanised and industrialised, the educational level of their residents was low). In this part of Poland lived many non-Poles (Ukrainians, Belarusians, Jews, Russians and Lithuanians), who were hostile to Polish statehood. Therefore, the Polish government, through administrative (strengthening local government institutions), economic (the establishment of military and civilian Polish farms), ethnic (limitations of the rights of ethnic minorities), cultural-educational (the promotion and sponsorship of Polish culture, the growth of public education), and migratory (sending Polish civil servants and their families) policies, pursued the assimilation of the eastern borderlands. ${ }^{10}$ It also did not spare the city of Vilnius, where the rights of the non-dominant ethnic population group were restricted (a prohibition on holding certain positions, narrowing the options for education in the mother tongue, etc). It is complicated to evaluate the contribution of the assimilation actions to ethnic changes in the city. However, the data available indicates that Poland's pursued migration policy significantly affected ethnic changes in Vilnius, and had an effect on the very assimilation process.

The chosen chronological range marks the period of the history of 'Polish' Vilnius, which began in 1920 after the 'rebel' L. Żeligowski took over the city, and ended with the beginning of the Second World War, when in the fall of 1939 Vilnius became an

${ }^{10}$ E. Kirwiel, Kresy Pólnocno-Wschodnie Rzeczypospolitej Polskiej w latach 1918-1939 (Lublin, 2011), pp. 16-24, Z. Żołędowski, Białorusini i Litwini w Polsce, Polacy na Białorusi i Litwie (Warsaw, 2003), pp. 111-119. 
integral part of Lithuania, into which poured many thousands of war refugees from the part of Poland occupied by Germany.

\section{The demographic situation in Vilnius and its dynamics}

In the demographic development of the city of Vilnius, the following steps were exclusive:

1) in 1920-1932 when the city's population grew intensely until 1925, but a few years later the growth rate decreased, but did not stop; 2) in 1932-1939 when the city's demographic situation remained almost unchanged. In the first stage, the population grew the most due to migration processes from Russia and other places in Poland. However, the economic crisis in Europe, begun at the end of the 1920 s and continuing, halted the growth in the city's population.

It should be noted that the border between these phases coincided in Poland with the introduction of a new procedure for calculating the population. Its essence was this: the former address-registration offices and registration books of permanent residents were replaced by registers of all residents, in which permanent residents were recorded and the movement of the population was fixed (people coming for a temporary visit or departing). This procedure came into effect on 1 July $1932^{11}$.

The first table shows the dynamics of the population in the city of Vilnius.

Data from 1913, which recorded the population of Vilnius before the First World War, was deliberately included in the table. In 1916, the census data on the population of Vilnius carried out by the German government showed that due to the war there was a very significant decline in the population ( 41 per cent), because Russians, Jews and Poles had fled to Russia. The 1920-1939 data is approximate. The Vilnius Central Bureau of Statistics did not have accurate data on the number of inhabitants; it followed reference figures, which were derived by a method of theoretical calculation. Therefore, according to one set of data, 183,000 people lived in the city in 1932; but by another, 201,000 ${ }^{12}$. In 1934 and 1935, the city's population was obtained by adding the natural growth to the

11 30.04.1932 circular of Poland's IAM (Internal Affairs Ministry), LCVA, f. 53, ap. 23 , b. 210 , fo. 14ap.

${ }^{12}$ General data on Vilnius city real estate in 1932 and 1936, LCVA, f. 64, ap. 20, b. 812, fo. 16; data on Vilnius city population and movement, ibid., b. 921, fo. 22 . 
population at the end of 1933 , and not taking into account the mechanical growth at all. In some years it was quite high. For instance, in 1937 it was 10,652 people $^{13}$. By this principle, the population was calculated until the beginning of 1939. Somewhat later, the Statistics Division recalculated the city's population. It was a little more than $192,000^{14}$. From the data provided in the table, one can see that the city's population grew particularly at the beginning of the 1920 s, when in a few years it increased from 128,000 to 167,000 , i.e. about 40,000 . This rise was mainly due to mechanical gain. Already in the second half of 1919, former city dwellers who had moved to Russia during the First World War began to return to the city. It was calculated that about 88,000 former residents of Vilnius had left. For instance, in September-December 1919, 4,067 Poles, 107 Russians, 319 Lithuanian, and 9 people of other nationalities came to the city ${ }^{15}$. In September 1921 to July 1922, about 10,000 former residents of Vilnius returned to the city ${ }^{16}$. However, not only former city residents came to Vilnius. Russian refugees from Soviet Russia, as well as Poles from other places in Poland, the eastern part of Belarus and Lithuania, poured in the city. Moreover, with the purpose of colonisation (which is understood as the settlement of the dominant population group [Poles] in less populated borderlands of the country), especially in 1923, when the question of Vilnius belonging to Poland was resolved at the international level, administrative, economic and science-education institution employees were sent to the city from Central Poland. For example, at various times judges, police officers, military personnel, various directors and employees of organisations, teachers, and students arrived in Vilnius from Warsaw or other places ${ }^{17}$. At the Vilnius Seminary in 1925 and 1926, in the first to third years there were about 90 semi-

13 Statistical data on mechanical growth in Vilnius in 1937, LCVA, f. 64, b. 948 , fo. 2-96.

${ }^{14}$ Population of Vilnius city according to sex, age, religion, native language, and literacy, ibid, b. 986-990.

15 The October-December 1919 bulletin of the Vilnius city central statistics bureau, MAVB RS, f. 29-321, fo. 98.

${ }^{16}$ Letter from the deputy of the Vilnius city elder of 22.07 .1922 to the Polish government delegate in the Vilnius region, LCVA, f. 51, ap. 15, b. 1169, fo. 93.

17 Registration cards of Vilnius city residents, ibid., f. 64, ap. 28, b. 409, 510-511; Registration book of the residents of M. Magdaleny and Shapowa st. No. 4/11 house in Vilnius, MAVB RS, f. 318-34790, fos. 8-47. 
narians, of whom only a few were from Vilnius or the surrounding areas ${ }^{18}$. Many youths had come from central provinces of Poland.

\section{Table No. 1. The population of the city of Vilnius in 1920-1939}

\begin{tabular}{|l|l|}
\hline Year & Population \\
\hline 1913 & 238,689 \\
\hline 1916 & 140,840 \\
\hline 1920 & 128,476 \\
\hline 1922 & 161,785 \\
\hline 1923 & 167,454 \\
\hline 1925 & $180-190,000^{*}$ \\
\hline 1927 & 173,730 \\
\hline 1928 & $190,172 * *$ \\
\hline 1930 & about 200,000 \\
\hline 1932 & 195,071 \\
\hline 1933 & 201,125 \\
\hline 1935 & 207,117 \\
\hline 1936 & 207,750 \\
\hline 1937 & 197,242 \\
\hline 1939 & 209,442 \\
\hline
\end{tabular}

* The Vilnius City Statistics Division noted that this is an estimate of the city's population.

** According to other data of the Vilnius Statistics Division, 184,980 people lived in the city, LCSA, f. 64 , ap. 20, b. 218 , fo. 4.

The table is based on Pamiatnaia knizhka Vilenskoi Gubernii, Part 2 (Vilnius, 1913), p. 1926, first quarter statistical report $L C V A$, f. 64, b. 743, fo. 5; M. Brensztejn, Spisy ludności m. Wilna za okupacji niemieckiej od d. 1 listopada 1915 r. (Warsaw, 1919), p. 21; report of the Vilnius City Magistrate Statistics Division on labour in May 1925, ibid., b. 703, folios not numbered; Vilnius city police data about the population in 1927 , ibid., b. 761 , folios not numbered; data on the population of Vilnius and its movement, ibid., b. 921, fo. 22; b. 920, fo. 146; Vilnius city president's letter of 10.06.1930 to the Board of the Union of Poland's Cities, ibid., b. 128, fo. 49; general data on Vilnius city properties in 1932 and 1936, ibid., b. 812 , fo. 16; Vilnius city population by sex, age, religion, native language and literacy, ibid., b. 986-990, 18.11.1925 letter to the Polish government representative in Vilnius, ibid., f. 51, ap. 4, b. 915, fo. 7; Drugi powszechny spis ludności z dn. 9.XII.1931 r. Miasto Wilno, p. 1; R. Žepkaite, Vilniaus istorijos atkarpa 1939-1940 (Vilnius, 1990), p. 49.

One may note that the government bureacracy here was extraordinarily inflated. In 1922, representatives in Vilnius of the Polish

18 List of 1-3 course seminarians at Vilnius Seminary, ibid., f. 342-39741, fos. $1-8$. 
Government Delegation to the Vilnius region, which was beginning to function, observed that the number of employees in institutions in Central Lithuania was too large, and began to reduce it ${ }^{19}$. But this was only a temporary measure. In 1931, Vilnius had 98 institutions, with over 33,000 officials and workers ${ }^{20}$. For comparison: in all of Lithuania at the time, there were about 25,000 employees. The large number of officials sent to Vilnius gradually determined the differentiation and frustration of society: the newcomers felt unjustly humiliated, they had arrived in a backward land, while the local residents felt underestimated. An issue of Kurier Wileński in 1936 wrote:

'The policy of transferring state officials to remote locations separated the ruling and the ruled, the top and the bottom, with a wall of mistrust [...] The elite of the new arrivals did not seek a closer cultural and social coexistence with the local residents. No wonder that they did not do this, but also no wonder that in the depths of his [the elite of the newcomers] heart was hiding the wrong for the peculiar exile. The locals feel treated as something worse, they feel that their children do not have any chance to occupy high positions in society, since the newcomers, or in the best case the local nobles, will take all of them.' ${ }^{21}$

The rates of migration to the city did not decline in subsequent years. For instance, in the months of January-June and October-December 1925, the mechanical growth was more than 9,500, and in $1927-1928$ it was $26,728^{22}$. In reality, it was higher, because some of the new population avoided registration. Poland's Central Statistical Office stated after the 1931 census that in the 1920s the most intensive demographic changes occurred in Vilnius, which was first among all the major cities of the country. Its growth was about 53 per cent ${ }^{23}$ (for comparison: in second place was Bydgoszcz, where

19 The report about the work of the special discipline section of the Polish Government Delegate to the Vilnius region institution from the beginning of the section's work up to the middle of September 1924, LCVA, f. 51, ap. 15, b. 25 , fo. 3. There is evidence that there were about 7,000 Central Lithuanian officials, S. Vancevičius, Teisinis režimas Vilniaus krašte 1920-1939 metais (Vilnius, 1973), p. 11.

${ }^{20} 1941$ memorandum about the nationality distribution of residents of Vilnius city and region, MAVB RS, f. 165-911, fo. 4.

${ }^{21}$ P. Lemiesz, 'Elita napływowa czyli uczymi się etnosocjologji', Kurier Wileński, 25 Sept. 1936, p. 1.

${ }^{22}$ Movement of Vilnius city residents on 6 Jan. 1925, 10-12, LCVA, f. 64, ap. 20, b. 702, fos. not numbered; Rocznik statystyczny Wilna 1921-1928, p. 19.

2314 Jan. 1932 a press bulletin of Poland's Central Statistical Office's National Census Bureau, MAVB RS, f. 245-217, fo. 17. 
the population increased by 34.1 per cent, in third place was Lodz, by 34 per cent).

The city's economic situation unquestionably had an influence on migration. Vilnius was an administrative, trade-services, culturescience centre that attracted people. However, compared to other Polish cities, it was poor. For example, in 1926 residents of the city paid income tax of little more than one million, while Poznan residents paid 5.1 million. ${ }^{24}$ The city's industry, which guaranteed higher earnings, was also meagre. Due to the crisis that engulfed Poland in the early 1930s, industry in Vilnius declined even further. In 1932, industry employed about two thousand people ${ }^{25}$. Therefore, not only in industry, but also in trade, and in the public sector in Vilnius it was hard to expect higher wages. Due to the crisis in the city, unemployment increased. Therefore, it became much more difficult for non-residents of the city to find employment. This circumstance reduced migration to Vilnius. The situation was similar in other cities of Poland, where migration from villages also decreased $^{26}$. Vilnius voivodeship residents started looking for better earnings in other countries: Latvia, France, North and South America. The remaining material shows that from the beginning of the 1930s, every year several thousand inhabitants of the voivodeship worked in other countries ${ }^{27}$. Available data shows that residents of Vilnius also went abroad to work.

By the orders of the Provisional Governing Commission of Central Lithuania, registration of the population came into effect from August 1921. It was mandatory ${ }^{28}$. An exception was provided for citizens of Poland with documents issued by government structures and foreigners who had received visas from Polish consulates.

24 Report on Vilnius city territory, residents, legal, economic and financial conditions in 1919-1929, LCVA, f. 64, ap. 20, b. 218, fo. 4.

${ }^{25}$ Rocznik statystyczny Wilna 1931 (Vilnius, 1933), p. 103.

${ }^{26}$ A. Kicinger, 'Polityka emigracyjna II Rzeczypospolite', (Central European Forum for Migration and Population Research) CEFMR Working Paper, 2005, No. 4, p. 21, access through <http://www.cefmr.pan.pl/docs/cefmr_wp_2005-04. pdf $>$ [address visited on 20-06-2012].

2730 Jan.1931 letter from Poland's consul in Daugavpils, M. Babiński, to the Vilnius voivodeship office, LCVA, f. 51, ap. 12, b. 1022, fo. not numbered; 28 Sep. 1933 report of Vilnius voivodeship voivode, ibid., b. 1887, fo. not numbered; 1 Feb. 1933 request of H. Szczepułkunowa to Dysna District starosta, ibid., fo. not numbered.

${ }^{28}$ Decree of the Provisional Governing Commission of Central Lithuania of 29 Aug. 1928, LCVA, f. 64, ap. 13, b. 123, fo. 142-150. 
Mostly people of Polish nationality came to the city. The available statistics show that in December 1925 the mechanical increase was 1,005 people, of whom 809 were Poles, 139 Jews, 44 Russians, four Lithuanians, and nine others. In April-June 1927, the mechanical growth of Poles was 1,034 people, of Russians 54, of others 66, but the growth rate of Lithuanians, Belarusians and Jews was negative ${ }^{29}$. We do not have data on total mechanical growth during the period. Lithuanian historiography indicates that in 1920-1939, about 100,000 people came to Vilnius, including 42,649 workers and their families, 32,073 Polish officers and their families, 9,546 pensioners and war invalids, and 3,862 military families ${ }^{30}$. However, included in this number apparently were also part of the indigenous population of the region, since, according to Ignas Šeinius, the Lithuanian Red Cross representative in Vilnius area, it would be difficult to believe that such a large number of workers and their families would move to a city not guaranteeing higher wages ${ }^{31}$.

The data in the second table confirms that the city's population grew mainly due to mechanical growth. The natural increase had little effect on the city's demographic change, and its significance kept decreasing.

\section{Table No. 2. The natural population increase in Vilnius in 1920-1939}

\begin{tabular}{|l|l|}
\hline Year & Natural growth \\
\hline 1920 & -922 \\
\hline 1921 & 1,188 \\
\hline 1922 & 2,067 \\
\hline 1923 & 2,749 \\
\hline 1924 & 2,160 \\
\hline 1925 & 2,532 \\
\hline 1926 & 2,241 \\
\hline 1927 & 1,691 \\
\hline 1928 & 1,212 \\
\hline 1929 & 947 \\
\hline 1930 & 1,252 \\
\hline
\end{tabular}

${ }^{29}$ Data on the movement of residents of Vilnius city in December 1925, ibid., f. 64 , ap. 20, b. 702 , fos. unnumbered; Statistical account of the mechanical growth of Vilnius city in the second quarter of 1927, ibid., f. 64, b. 460, fo. 21.

${ }^{30}$ G. Surgailis, 'Lenkai, Antrojo pasaulinio karo atbėgèliai, Lietuvoje (1939 m. rugsèjis - 1940 m. birželis)', Rytu Lietuva (Vilnius, 1992), p. 113; Žepkaitè, Vilniaus istorijos atkarpa, pp. 49, 58.

${ }^{31}$ Lietuvos ir Lenkijos santykiai 1917-1994: dokumentu rinkinys, ed. V.P. Plečkaitis, J. Widackis (Vilnius, 1998), p. 134. 


\begin{tabular}{|l|l|}
\hline Year & Natural growth \\
\hline 1931 & 1,161 \\
\hline 1932 & 937 \\
\hline 1933 & 695 \\
\hline 1934 & 223 \\
\hline $1935-1938$ & 1,530 \\
\hline $193901-06$ & 129 \\
\hline Total & 21,792 \\
\hline
\end{tabular}

The table is based on Rocznik statystyczny Wilna 1921-1928 (Vilnius, 1930), p. 22; Rocznik statystyczny Wilna 1931, p. 14; Rocznik statystyczny Wilna 1937 (Vilnius, 1939), p. 10; 09.02.1939 report by the Chief of the Central Statistical Bureau of the Vilnius Magistrate to the Central Statistical Board in Warsaw, LCSA, f. 64 , ap. 20 , b. 963 , fo. 3 .

\section{The regulation of demographic processes in Vilnius by Poland's administrative government}

The city's political administrative authorities at that time regulated the city's ethnic-demographic processes. The streams of newcomers to the city began to be limited. Those desiring to return to Vilnius and settle had to get government approval. Surviving documents testify that not only whether the person was a permanent resident of the city before the First World War was checked, but also his property, political views, moral provisions, and attitude to the Polish identity. For instance, in 1921 a former Russian resident of Vilnius was not allowed to return, because, according to the police commissioner, 'his father was anti-Polish, so it follows that the son was also brought up in an anti-Polish spirit?' ${ }^{32}$

In providing permits to come to Vilnius, a negative answer for some individuals was determined by not being a permanent resident of the city. However, at the same time, there were no hindrances other people who had never lived in Vilnius. Most of them were Poles. For instance, on 10-15 December 1921 new residents of Vilnius in police departments were registered: more than 40 Poles, ten Jews, eight Russians, four Lithuanians, and one Tartar. ${ }^{33}$

Due to the desire of a large number of people of non-Polish nationality to return to Vilnius, the city's commissioner Kazimierz

${ }^{32}$ Report of 14 Aug. 1921 from the Vilnius city III police district commissioner to the Vilnius city elder, LCVA, f. 53, ap. 23, b. 5, fo. 231.

${ }^{33}$ Lists of persons returning from abroad and registered with the police, ibid., b. 11 , fos. $41-81$. 
Wimbor evaluated their return very carefully. ${ }^{34}$ Such a 'careful' practice had been applied since 1921, when the leadership of Central Lithuania announced that it would admit only those who had left Vilnius after the actions of L. Żeligowski and had permits to return, while refugees from Russia and those who had emigrated before 8 October 1920 would not be admitted. ${ }^{35}$ This meant constraints on migration to Vilnius. From the summer of 1921, Poland did not admit Jews from Russia. ${ }^{36}$ They were viewed as having taken an opposing and unfavourable position with regard to Poland's statehood and the country's government. ${ }^{37}$

The Institute of Polish Citizenship was also used to control demographic processes. According to a decree of the Central Lithuanian Army High Command on 7 January 1921, citizenship was to be granted to five categories of person: 1) people recorded in lists or books of local residents of Central Lithuanian territories, 2) people born in Central Lithuania or having property and living here before 1 January 1919 ; 3) people who up to 1 August 1914 had lived for at least five years in Central Lithuania; 4) people living in Central Lithuania from 1 January 1918 and having a permanent place residence here; 5) people working in state and municipal institutions ${ }^{38}$. Citizenship was also granted to the spouses and children of the people mentioned. However, during the war, the population registration books, which were essential for citizenship, had been severely damaged. Therefore, the process of granting citizenship proceeded slowly. It was not easy for people of non-Polish nationality to obtain Polish citizenship. At the end of 1922, the Polish government delegate issued an instruction that all people of non-Polish nationality who did

${ }^{34}$ Report of Vilnius city commissioner K. Wimbor about his work in October 1922, ibid., ap. 15 , b. 26 , fo. 15 .

${ }^{35}$ Report by the chief of the Central Lithuanian supreme commander's bureau on 09.02.1921 to Poland's government delegate in Vilnius, ibid., b. 2865, fos. not numbered.

${ }^{36}$ T. Balkelis, 'Lietuvos vyriausybė ir Pirmojo pasaulinio karo pabėgèlių repatriacija ị Lietuvą, 1919-1924', Oikos, 2006, No. 2, p. 66.

${ }^{37}$ Report by Vilnius parish about its work in September 1922, LCVA, f. 51, ap. 15 , b. 26 , fo. 20 ap.

${ }^{38}$ Decree No. 56 of the Central Lithuanian army's supreme commander on 7 Jan. 1921, ibid., f. 64, ap. 13, b. 123, fos. 10-13. 
not have Polish citizenship and had arrived after 15 June 1920 had to depart from Vilnius by 1 March $1923 .{ }^{39}$ In the following year, the leaders of the districts governed by the delegate were instructed that citizenship could be granted to members of ethnic minorities only if there was not the slightest doubt that the applicant had the right to it. In the event of the smallest uncertainty, it was necessary to perform a comprehensive review, and if any kind of inconsistency in the data appeared, to reject the request. ${ }^{40} \mathrm{~A}$ person who was not a citizen of Poland could be deported from the country at any time, and could not hold certain positions (such as a teacher at a private school). The strict execution of the instructions determined that in the spring of 1927 about 35,000 residents of Vilnius were recorded in a third list, on which were included individuals who did not meet the conditions for obtaining citizenship (i.e. they were not born in Vilnius and did not have property or business there before the war, or did not have the appropriate documents. ${ }^{41}$

In the spring of 1928, the President of the Republic of Poland authorised the administrative authorities of the voivodeships to organise and control the movement of the population. ${ }^{42}$ In carrying out this instruction, the registration of people arriving in Vilnius and departing for more than 24 hours was begun, and special registers were started. In them, information about a person's residence in a particular place, their nationality (on the basis of what documents it was granted, it was noted if it was rescinded, and so on), criminal record, marital status, livelihood, and so on, was recorded. ${ }^{43}$

${ }^{39}$ Report of Polish government delegate on 22 Dec. 1922, ibid., f. 51, ap. 15, b. 13 , fo. 97 .

${ }^{40}$ Report by the administrative section of the Polish government's delegation on 25 Aug. 1923 to the elder of the Dunilov district, ibid., b. 417, fo. 51.

${ }^{41}$ Letter by the government commissioner of 2 Apr. 1927 to the Vilnius administrative section, ibid., 4 , b. 89 , fo. 61 .

42 Decree of the President of the Republic of Poland on 16 March 1928 on the control of the movement of population and accounting, Dziennik Ustaw, 1928, no 32 , poz. 309 , pp. 608-609.

${ }^{43}$ Circular No. 56 of the Internal Affairs Ministry of the Republic of Poland of 30 Apr. 1932, LCVA, f. 53, ap. 23, b. 210, fos. 11-14; October 1937 letter of the Vilnius voivode to the public-political section about the examination of the work of the Vilnius city population registration bureau, ibid., f. 51, ap. 7, b. 1069, fo. 51 . 


\section{Plans of the censuses of the Vilnius population and their implementation (in 1923-1931)}

During the period analysed there were two general censuses in Poland (1921 and 1931). However, the first census did not include Vilnius, and therefore on 30 August 1923 the Polish Council of Ministers adopted a decision to carry out a general census of the population of Upper Silesia and the Vilnius region. ${ }^{44}$ However, this decision was cancelled and the population census was postponed.

In 1925, there was a return to the idea of a population census of the Vilnius region. The census was prepared: census forms were sent from Warsaw, census takers were found. However, a few days before the start of the census, it was again cancelled. ${ }^{45}$ Why was the decision made to cancel the censuses in the Vilnius region in 1923 and 1925 ? The official reason was the lack of funds. ${ }^{46}$ However, one suspects that the census did not take place not only for this reason. For example, in the Belarusian language newspaper Bielaruskaja Niwa it was explained that the Polish government postponed the census in the Vilnius region for five years [until 1925], because it first had to 'strengthen the Polish character' in those areas, they had to be flooded with thousands of Polish employees sent from ethnographic Poland, Polish newcomers had to be settled, all the Belarusian schools had to be closed and Polish schools established everywhere, and only then begin to 'clarify' the ethnic composition of the population in this part of Poland. ${ }^{47}$ One can assume that the not entirely clear ethnic composition of the population of this region may have influenced the decision to postpone the census. The census of inhabitants of Vilnius city and region took place only in 1931.

In order to avoid errors in the September 1921 census (an inappropriately chosen time, when due to agricultural work many residents were not at home), in 1931 the population census was held in the winter, on 9-13 December, residents of Vilnius were registered by 1,589 enumerators, whose work was controlled by 95 senior and 22

${ }^{44}$ List of laws and ordinances regulating the censuses of the population, ibid., f. 64 , ap. 20, b. 692, fos. not numbered, 11 Jan. 1924 letter from the Polish Ministry of the Interior to the government delegate in Vilnius, ibid., f. 51, ap. 15, b. 541, fo. 1.

${ }^{45}$ List of laws and ordinances, regulating the population censuses, ibid., f. 64 , ap. 20, b. 692, fos. not numbered.

46 'Spis, który się nie odbył', Przegląd Wileński, 10 Jan. 1926, p. 5.

${ }^{47}$ Bielaruskaja Niwa article 'New plebiscite' on 16 Dec. 1925, LCSA, f. 51, ap. 15 , b. 592 , fo. 6 . 
district census commissioners ${ }^{48}$. It was calculated that one enumerator would register 250 inhabitants. Compared with the census planned in 1925, this time there were more than twice as many enumerators (720 in 1925, 1,589 in 1931). Such a large group of enumerators in 1931 was due to the very large number of people wishing to register the population. However, only politically reliable people, mostly Poles, were chosen. They numbered 1,250 (moreover, 369 Jews, 65 Russians, 34 Belarusians, five Ukrainians, three Karaites, one Lithuanian and one German were also recorded) ${ }^{49}$.

According to official data, during the 1931 population and housing census, 195,071 people, 88,290 men and 106,781 women, were registered in Vilnius ${ }^{50}$. However, according to the data of the Vilnius city chief census commissioner T. Nagurski, 196,668 people were recorded ${ }^{51}$. One may question how exact this number is, and whether all the residents were registered. We would think that the total population of the city of Vilnius was calculated more or less objectively, and that there was an attempt to register all the people (including the homeless). However, the data on the ethnic composition of the population is questionable. In the 1931 census, unlike in 1921, there was no question about nationality. There was only a question about the native language. In this way, according to the General census commissioner Dr R. Buławski, the possibilities for misunderstandings would be reduced, because the language criterion was more objective than that of nationality ${ }^{52}$.

Immediately after the census, residents of various nationalities complained that the information they furnished was not always correctly noted. For example, in the city of Vilnius, a Lithuanian student asked that his native language be registered as Lithuanian language. After hearing this request, the face of the Polish enumerator became sullen and he asked, 'How is it? Why? Does

${ }^{48}$ Vilnius city census commissioners according to native language, ibid., ap. 2a, b. 282 , fo. 101 .

49 Vilnius city census takers according to native language, ibid. According to other data, there were 1,259 Polish enumerators, 338 Jews; Januszewska-Jurkiewicz, Stosunki narodowościowe, p. 505.

${ }^{50}$ Drugi powszechny spis ludności z dn. 9. XII. 1931 r. Miasto Wilno (Warsaw, 1937), p. 1.

${ }^{51}$ The summarised results of the Vilnius city population and housing census on 09 Dec. 1931 d, LCVA, f. 51, ap. 4, b. 503, fo. 28.

52 'Wywiad z Generalnym komisarzem spisowym dr Rajmundem Buławskim', Sprawy Narodowościowe, 1932, no 1, pp. 1-2. 
the gentleman say his prayers in Lithuanian?' After receiving two positive answers, reluctantly, with much hesitation, after a while, he put down the Lithuanian language ${ }^{53}$. Another Jewish resident of Vilnius also complained that the enumerator had told him to sign the census, although he had not completed the section about the native language. To his protest about this, the enumerator, departing angrily, said: 'You will speak Yiddish in Palestine' ${ }^{54}$. Soon after the census there was an article in the Vilnius Yiddish publication Vilner Tog about the arbitrariness of the results. Its author declared that most Lithuanians, Belarusians and Russians living in the Vilnius region did not indicate their real mother tongue, for fear of disadvantaging themselves when paying taxes, or obtaining employment, or the fear of losing it ${ }^{55}$. Shortly after the census, a group of members of the Sejm led by Fabjan Jeremicz addressed the Polish Council of Ministers about the falsification of data. He claimed that in the eastern voivodeships, Belarusians were registered as Poles, while their children attending Polish schools automatically became Poles ${ }^{56}$. However, their application to correct the errors remained unheard.

T. Nagurski, the city's chief census commissioner, also wrote about the lack of objectivity in the native language data of the Vilnius population. In a report, he pointed out that it would be inaccurate to determine the ethnic composition of the population of Vilnius according to native language, because some people of non-Polish nationality (e.g. Belarusian) reported Polish as their native language, not because they actually spoke it, but to stress their Polish identity. He also pointed out that in census district number No. 923 (Lukiškès prison) the data on native language was unobjective because the enumerators applied pressure to indicate the Polish language ${ }^{57}$.

The instructions given to the enumerators bear witness to a bias on the ethnic composition of the population in the census data. In November 1931, census courses took place in Švenčionys, dur-

${ }^{53}$ Information from a Lithuanian student in Vilnius on 10 Dec. 1931, MAVB RS, f. 246-1763, fo. 1.

54 'In Poland Jewish is not spoken', Owent Kurjer, 13 Dec. 1931, LCVA, f. 51, ap. 2a, b. 282, fo. 112 .

55 'After the census of the population. Impressions of the enumerator', Vilner Tog, 22 Dec. 1931, ibid., ap. 4, b. 501, fo. 14.

${ }^{56}$ Interpellation of a group of Sejm members to Poland's Council of Ministers on 12 Jan. 1932, ibid., ap. 2a, b. 282, fos. 90-91.

${ }^{57}$ Report by the Vilnius city chief census commissioner T. Nagurski about the population census, ibid., ap. 4 , b. 503, fos. 274, 281-282. 
ing which it was explained how to determine the native language of mixed families. When the course instructor was asked how to register children, if the father was Lithuanian, and the mother a Pole, who wanted to register the children as Poles, but the father objected, the answer was given: 'It should be clear to everyone that the mother has a greater influence on the childen than the father, thus, the children have to be registered as Poles.' When another attendee asked how to act if the mother was Lithuanian but the father a Pole, demanding that the children be registered as Poles, but with the mother demanding that they be registered as Lithuanians, the lecturer this time explained differently: 'When a woman weds a man, she gets the last name of her husband, so at the same time, she is no longer a Lithuanian woman, and thus the children have to be registered as Poles. ${ }^{58}$

Some Polish scholars claim that the census data is not objective, especially in terms of the ethnic composition of the population. J. Tomaszewski says that the size of Polish population was increased, and the number of non-Poles reduced. According to him, the Central Statistical Office admitted that it was forbidden to publish census data for smaller territorial units than the parish, because discrepancies in the composition of the ethnic population would become clear ${ }^{59}$. Moreover, researchers were forbidden to use authentic census material.

The measures taken by the Polish administration in a short time affected the ethnic composition of the city. Statistical data show that in Vilnius, Poles began to dominate.

The data in the table is approximate. It shows that after 1931 the city's population and ethnic composition remained almost unchanged, although it had to change somewhat due to natural growth (in 1932-1939 the natural growth comprised 3,514 people). On the other hand, one should also bear in mind mechanical growth, because the migration process to Vilnius at that time had not broken off. Officials from the Statistics Division of the Vilnius City Magistracy, after noting the ethnic composition of the population of the city in 1939, mentioned that they used the 1931 census data, which, as is known, recorded not nationality but native language. In this way, all

58 Correspondence from Švenčionys about the 22 Nov. 1931 course for enumerators, MAVB RS, f. 246-1241, fo. 1.

59 Tomaszewski, Ojczyzna nie tylko Polaków, p. 37. 
users of the Polish language were turned into Poles, of whom there were about $130,000^{60}$. Therefore, the Tartars, some Jews, Karaites and Belarusians became 'Poles'.

\section{Table No. 3. The ethnic composition of the population of Vilnius in 1920-1939}

\begin{tabular}{|l|l|l|l|c|c|c|c|c|}
\hline Year & \multicolumn{6}{|c|}{ Population according to nationality (in thousands) } & \\
\hline & Poles & Jews & $\begin{array}{c}\text { Lithuani- } \\
\text { ans }\end{array}$ & Russians & Belarusians & Tatars & Other & Total \\
\hline 1920 & 72.0 & 46.5 & 2.9 & 4.0 & 1.8 & & 1.2 & 128.4 \\
\hline 1923 & 100.8 & 56.2 & 1.4 & 4.7 & 3.9 & 0.3 & 0.4 & 167.7 \\
\hline 1929 & 104.0 & 67.0 & 2.5 & 11.0 & 1.0 & 0.2 & 1.3 & 187.0 \\
\hline 1931 & 128.6 & 54.6 & 1.6 & 7.4 & 1.7 & & 1.1 & 195.0 \\
\hline 1939 & $128.4^{*}$ & $53.5^{*}$ & 1.4 & 7.2 & 1.5 & 0.1 & 2.5 & 194.6 \\
\hline
\end{tabular}

* In reality, the number of Poles and Jews in the city was higher than what was cited by the Statistics Division of the Vilnius City Magistrate, because their migration to Vilnius in 1932-1939 had not been interrupted.

The table is based on the 1919-1931 Vilnius city population by nationality, LCSA, f. 64 , ap. 20 , b. 621 , fo. 2; the report of the Polish government delegate in Vilnius on 17.03.1923 to the Ministry of Religions and Public Information, ibid., f. 51 , ap. 15 , b. 210 , fo. 17 ; the Vilnius city population according to sex, age, religion, native language and literacy, ibid., f. 64, ap. 20, b. 986-990, JanuszewskaJurkiewicz, Stosunki narodowościowe, p. 495.

From the table, one can see that the Polish population in the city changed the most. As has already been mentioned, the main factor behind these changes was the migration of Poles to Vilnius, especially at the beginning of the period analysed. Due to the same factor (migration), at the same time the number of Lithuanians decreased. Many of them left Vilnius for Kaunas before L. Żeligowski took over Vilnius. In 1921, some of them returned only to take personal belongings ${ }^{61}$. Among these were the famous Lithuanian activist and poet Kazys Binkis (1893-1942), a founder of the Lithuanian Social Democratic Party and other organisations, and physician Andrius Domaševičius (1865-1935), the physician Vladas Kairiūkštis (1887-1967), and others.

${ }^{60}$ Data about the Vilnius city population on 1 Jan. 1939, ibid., f. 64, ap. 20, b. 963 , fo. 13 .

${ }^{61}$ List of people travelling to Vilnius to take their belongings, LCVA, f. 53, ap. 23 , b. 13 , fo. 34 . 
It is difficult to determine why the number of Russians in the city changed in 1929-1931. Greater migration processes at the time among them were not fixed. One may assume that at the end of the 1920 s, there were actually fewer Russians than is indicated in the table, because the city government made rough data available. The 1931 census showed a more accurate number of the city's Russian population.

Comparing the data in the table with other sources mentioned, we see a slightly different ethnic distribution of the city's population. According to the figures of the Vilnius Archdiocese, there were about 107,000 Poles in Vilnius in 1934, about five thousand Lithuanians, and about two thousand Belarusians ${ }^{62}$. According to the Lithuanian press, in the interwar period about 12,000 Lithuanians lived in the city ${ }^{63}$. However, the basis on which this number was obtained is not indicated.

The city centre (the Old Town) was the most densely populated. At the end of the period analysed, about 40 per cent (about 75,000) people resided there ${ }^{64}$. Jews, who numbered about 35,000 , comprised a significant part of the population of the district. Most Lithuanians and Belarusians in the city also lived there. Residents of Russian nationality were concentrated in the Rasos and Liepkalnis districts, which according to population was the third largest. About 27,500 people lived there, of whom 22,300 were Poles, about three thousand Jews, and about two thousand Belarusians ${ }^{65}$. Karaites resided mostly in the centre and Žverynas, where two-thirds of them lived. Most Tartars lived in the Rasos, Liepkalnis and Šnipiškès districts, while Germans lived in the Old Town and Užupis districts.

The New Town $(25,300$, of whom 16,000 were Poles and about seven thousands were Jews) and Šnipiškès $(25,100$, of whom 19,600 were Poles and four thousands Jews) were the most populated ${ }^{66}$. In

62 Statistical data of Vilnius Archdiocese for 1934, MAVB RS, f. 318-10271, fos. 1-2. According to the data of Lithuanian activists, in 1931 in Vilnius there were about 12,000 Lithuanians, Vilnius ir Vilniaus kraštas, p. 149. However, it is not revealed on what basis this figure was calculated.

${ }^{63}$ Gaučas, Etnolingvistine Rytu Lietuvos, p. 108.

${ }^{64}$ Statistical data about Vilnius city residents according to age, sex, religion, native language and literacy in 1939, LCVA, f. 64, b. 989, fos. 2-39; b. 989, fos. $233-285$.

${ }^{65}$ Statistical data about Vilnius city residents according to age, sex, religion, native language and literacy in 1939, b. 987, fos. 176-208.

${ }^{66}$ Ibid., b. 985 , fos. $242-278$; b. 990 , fos. $140-170$. 
other parts of the city (Užupis, Antakalnis, Žverynas) lived about 21,900 people, most of them Poles. Baltupiai, Jeruzale, Vilkpède, Pavilnis and Markučiai were the least populated. From one thousand to 4,500 people lived there ${ }^{67}$. Most of the poor people lived in the outskirts of the city and the suburbs.

\section{Conclusions}

Two phases, 1920-1932 and 1932-1939, stand out in the demographic development of Vilnius in 1920-1939. In the first phase, due to intensive migration processes and Poland's colonisation policies, the city's population grew very sharply, but it never reached its level before the World War First. In the second stage, the demographic situation remained stable, and the city's population remained virtually unchanged. This situation was probably mainly for politicaleconomic reasons, when due to ethnic policies or the radicalisation of the situation of the non-Polish population, their numbers in the city declined; and due to the difficult economic situation in the country, the direction of migration turned from internal (provincecity) to international (Poland-other state).

The demographic dynamics of Vilnius city were mainly influenced by mechanical gain, which accounted for two thirds of the total growth. The Polish government tightly regulated and influenced this process. The importance of natural growth in the city's demographic development was small, and was gradually declining even more. The main source supplementing inhabitants of the city was migration from rural areas in the Vilnius voivodeship and other voivodeships of Poland.

Poland's Citizenship Institute was used to control the ethnic processes in the city. Its provision or lack of it was a measure regulating the city's population and ethnic composition.

${ }^{67}$ Statistical data about Vilnius city residents according to age, sex, religion, native language and literacy in 1939 , b. $985,1.325-334$; b. 986, fos 125-134; b. 990 , fos $169-191$. 
Author Details

Vitalija Stravinskiene (b. 1972) is a researcher in the 20th Century History Department of the Lithuanian Institute of History. Her research focuses on the problems of Lithuania's ethnic Polish community in Soviet times.

Address: Lithuanian Institute of History, Kražių g. 5, Vilnius 01108

Email: stravinskiene@istorija.lt

\section{VILNIAUS MIESTO GYVENTOJAI STATISTINIŲ ŠALTINIŲ DUOMENIMIS (1920-1939 M.)}

Santrauka

\section{VITALIJA STRAVINSKIENE}

Straipsnyje, remiantis Lietuvos archyvine medžiaga, statistiniais šaltiniais ir istoriografija, nagrinėjama XX a. pirmosios pusès Vilniaus miesto etninè-demografinè raida, atskleidžiama etninių-demografinių pokyčių dinamika, ją nulèmę veiksniai.

Miesto etninèje-demografinèje raidoje išskirtini du etapai: 1) 1920-1932 m., kai daugiausia dèl migracinių procesų miesto gyventojų skaičius intensyviai augo; 2) 1932-1939 m. - stabilios padèties tarpsnis, kai demografinè situacija beveik nekito. Didžiausią ịtaką etniniams-demografiniams pokyčiams turèjo Lenkijos vykdyta etninė politika, kada politinėmis priemonėmis buvo kontoliuojami etniniai procesai Vilniuje ir vykdoma čia gyvenusių nedominuojančių etninių grupių atstovų asimiliacija. Aptariamu laikotarpiu Vilnius buvo lenkų ir žydų miestas, kuriame lenkai sudare apie 66 proc., žydai - apie 29 proc. miesto gyventojų. 